\title{
ПРЕД СВЕТЛОЗАРНИМ ЛИКОМ СВЕТОГА САВЕ И ПРЕД ДРУШТВОМ „СВЕТИ САВА“ - ПРОФЕСОРКА ДР ЈАСНА ЈАНИЋИЈЕВИЋ
}

\begin{abstract}
Научно дело социолога, културолога и комуниколога професорке др Јасне Јанићијевић утемељено је на савременим и модерним научним погледима какви су теорије информација, комуникација и рецепције. Напоредо и паралелно с тим налази се њен стручни и научни рад посвећен духовним вредностима традиције. У том другом сегменту најзначајније је вишегодишње њено ангажовање у Друштву „Свети Сава“, у којем је радила готово деценију и по врло предано и веома посвећено.
\end{abstract}

Кључне речи: Друштво „Свети Сава“, просвета, традиција, национално, врлина.

Колико год наизглед било парадоксално, издвојити бисмо појмове модернизам и традиција у светлу једног, можда и јединственог научног приступа. Модернизам схваћен као ново и савремено, тенденција осавремењавања, с тежњом да се одређени феномени усклађују с духом времена. Појам традиције могао би се означити и као преношење оних духовних чињеница које прелазе с генерације на генерацију, и то таквих на којима почива културни живот. Могу ли модернизам и традиција једно уз друго, или, могу ли и заједно?

Чини нам се да би такво становиште могло бити нарочито занимљиво при анализирању научног приступа професорке др Јасне (Стојков) Јанићијевић (1943 - 2013) социлога, културолога и комуниколога. Верујемо да је део одговора на постављена питања и у научном формирању. Још за време постдипломских студија боравила је у Холовеј колеџу код Лондона, као и на Универзитету у Авериствилу у Велсу, где је прикупљала грађу за свој магистарски рад о Џемсу Џојсу, као и у Кембриџу, где је похађала семинар савремене енглеске књижевности. Доцније се научно усавршавала у Француској (1985) и у Сједињеним 
Америчким Државама у три наврата 1987-1988, 1995. и 1997. године. Започела је универзитетску каријеру на Филолошком факултету у Београду 1971. године на предмету Социологија културе и уметности. ${ }^{1}$ У звање доцента изабрана је 1984. године; за ванредног професора 1995. за предмет културологија, а за редовног професора 2000. године. Поред општег курса бавила се и питањима културе и комуникације и држала посебан курс под називом „Теорија информација и комуникација“, а затим и друге курсеве на смеровима за Организацију културних делатности и Новинарство, као и курс из Културне анимације.

Назначили бисмо даље да се савремене теорије информација и комуникација развијају особито плодоносно у другој половини 20. века и то у духу схватања да готово не постоји област живота у чијем се средишту не налази информација. Док се на једној страни надовезује на токове који су јој претходили или који су изван ње, на другој има тенденцију да их сложи, да их кристализује. Баш тај информацијско-комуникацијски аспект долази нарочито до изражаја у теорији рецепције, испрва књижевној теорији, која се убрзо проширила у веома различите области закључно са журналистиком (Поточан 2011: 143). Све те тада нове, савремене, модерне теорије - информација, комуникација и рецепције - биле су довољно изазовне као део интересовања и научног промишљања професорке др Јасне Јанићијевић.

Никако насупрот томе, него напоредо уз таква интересовања, ангажована је у Националној комисији Унеска. Памте се њене заслуге и у међународном пројекту Women Beyound Borders, који је завршен репрезентативном изложбом дванаест ликовних уметница Србије, чија су дела излагана широм света. На њену иницијативу (у својству помоћника министра за културу Републике Србије 1989 - 1992) штампана је монографија о разореним споменицима Српске православне цркве у Хрватској у рату 1991 - 1992. године. Посебно бисмо издвојили велико лично ангажовање професорке др Јасне Јанићијевић у обнављању Друштва „Свети Сава““ и часописа „Братство“, као органа Друштва, чији је генерални секретар постала и предано радила готово деценију и по.

1 Млада, лепа, елегантна асистенткиња у „Сали хероја“ на Филолошком факултету, уз професора др Милоша Илића, за катедром, достојанствено ћути. Јесен 1971. Асистенткиња, о којој је реч, била је Јасна Јанићијевић. Био сам тада бруцош. Запамтио и ту јесен, и многе блиставе предаваче, и многе речи које се понесу за цео живот, и њу, асистенткињу која је, тако смерно и достојанствено, за катедром, умела и да ћути. Па, ево, да се ни то не заборави. 
Друштво „Свети Сава“ најстарије је активно српско грађанско друштво основано 1886, пре тачно 128 година. О Савиндану ове, 2014 године, обележене су две деценије постојања и рада од послератне обнове. У циљеве Друштва наводе се: ширење просвете и културе, неїовање националної осећањ а врлине и вредности светосавске традиције, као и култа Светога Саве у српском народу. Као задаци Друштва истичу се: објављивање пригодних књига, годишњег часописа „Братство“, сарадња са школама и црквама, организовање редовног Светосавског конкурса за ученике основних и средњих школа у Србији, Републици Српској, региону и расејању, ширење пододбора Друштва у Србији и српској дијаспори (Брайсииво [1997]: 9-10).

Предано радећи у Друштву „Свети Сава“, професорка др Јасна Јанићијевић посебно се посветила и изучавању свеукупног дела Светога Саве. Зато је тако посвећено излагала вредности светосавске традиције, верујући да на тај начин особито и лично подстиче неїоваъе наиионалної осећања врлине. Остале су незаборавне њене светосавске беседе, како оне на великим сценама у Београду, тако и оне у варошици Убу, или у Младеновцу, у Бјељини или у Бањалуци.

\section{Свети Сава у свом и у нашем времену}

Шекспир XX века, како неки називају драмског писца нобеловца Харолда Пинтера (Harold Pinter) ${ }^{2}$, у својој беседи 2005. године, поводом додељене му Нобелове награде за књижевност, оставио је аманетну поруку о данашњем времену. Означио га је као епоху у којој су истина и лаж на најмањој удаљености! Застрашујућа порука. И тешка,

2 Харолд Пинтер (1930-2008), један од најважнијих драмских писаца XX века... Пинтер је пример ангажованог писца и интелектуалца који се недвосмислено ангажовао у најважнијим јавним и политичким питањима последњих деценија $\mathrm{XX}$ века као изразити критичар питања политичке моћи у међународним односима и као страсни заступник људских и грађанских права. У идеолошком погледу левичар, Пинтер је у свом времену оличавао препознатљив глас друштвене критике. Пинтеров ангажман огледао се у многобројним публицистичким текстовима, јавним апелима и конкретним јавним и политичким акцијама у Великој Британији и у многим другим земљама. Догађаји на британској и светској политичкој сцени нису га остављали равнодушним, а ни његове одрешите реакције никог нису чиниле равнодушним. Према Пинтеровој књизи Нови свеииски йореgак, „Архипелаг“, Београд. 
веома тешка оптужба. (Као ни ове речи не бисмо смели заборавити ни да је Харолд Пинтер био пријатељ и поштовалац српскога народа и почасни доктор Крагујевачког универзитета). А уз овакве његове речи можда је лакше разумети зашто се о српском средњем веку, о Немањићима, о светосављу говори данас са готово самим негативним конотацијама - од Википедије до судница у Хагу. Па пошто је нажалост већ тако, да још мало разгрнемо срењовековне тмине не би ли се некако ипак пробила светлост истине. Из те епохе посебно се издваја XII век, првенствено по личностима предодређеним да обележе и тај век и, шире, епоху: „Дванаесто столеће! Плодно, пуно покрета и промена, доба богомила и катара, епоха Фрање Асишког и Саве Рашког, време крсташких ратова; тренутак кад се ишчезли антички свет буди и кад се кроз сумрак средњега века јављају прве зоре ренесансе и нашега модерног света.“ (Ковачевић 1959: 278) „(...) Готово као чуда из житија светитеља указују се дотад невиђена и непојамна чудеса. Изван црквеног брода, међу људима, као плод људског духа и ума: „Са својим радозналостима, јересима, експериментима и проналасцима јер то је доба првих ветрењача, компаса, механичких часовника, први тренутак кад се лекар усуђује да разуди тело мртваца - дванаести век је столеће немира, новина, буђења и изненађења.“ (Ковачевић 1959: 279) На тај силан замах новопробуђених нада средњовековног света силни су и одјеци: „Дванаести век је столеће великих плодности; после античких времена, ниједна дотадашња епоха не премашује га лепотама и духовном величином и снагом. Те плодности, лепоте и снаге одјекивале су и рашким брдима.“ (Ковачевић 1959: 291)

У тим рашким брдима рођен је принц Растко, најмлађи син жупана Стефана Немање. Када? Не зна се поуздано. И о најранијем детињству и младости Растка Немањића зна се мало. Зато је ту празнину с много труда настојао да попуни Милан Кашанин кад је образлагао: , При дефинисању његове личности, разматрању његове активниости и обележавању његовог књижевног рада, прво што треба имати у виду, то је да је он владарски син. Од раног детињства, он је живео одвојено, у засебној кући, с пратњом и васпитачима, у којој су га посећивали родитељи и где се дружио с дечацима свог узраста. Као и његова два брата, Вукан и Стефан - као и сва владарска и властеоска деца тога доба код нас и на страни - он је упознао Блиблију, догматику, етику, 
старословенски језик, граматичке законе, вештину писања, стилистику, математику. У својој шеснаестој години, он се, окружен младим властеоским синовима, не само забављао играма и одласком у лов и веселио свирком и певањем, него је већ управљао једним делом Хума. Пошто се у дечаштву научио молитви, писати, рачунати и читати, он се, као младић, учио водити послове и владати људима.“ (Кашанин 1970: 296)

И та његова велика мисија тек је имала да се развије после замонашења. Као да су му тиховања у молитви тек припрема за све што је намерио да оствари на Светој Гори: „Да је млади Растко отишао у манастир из љубави ка монашком животу и да је Сава целог века остао истински монах не може се сумњати. Али се не може сумњати ни то да он није провео дане у манастиру као `молчалник` и испосник. Више но једнострано медитативан, он је био свестрано активан. Још веома млад, далеко од куће, сам, дао је сазидати у Ватопеду три цркве и, поред њих, не с мање воље, манастирске конаке. По Немањину доласку у Свету Гору, у манастиру Просфори је подигао цркву и око ње утврђење с кулом, обновио манастире Каракал и Ксиропотам, дао израдити фреске у цркви Четрдесет мученика, бринуо о манастиру Зигу и Милејима. У исто време, прихватио се да оснује у Светој Гори манастир за Србе монахе, и основао у томе циљу манастир Хиландар, у коме је обновио и дао живописати цркву, сазидати конаке, утврдити бедеме и подићи пирг. ${ }^{3}$ По повратку у Србију, прво што је учинио, то је завршио и живописао Богородичину цркву у Студеници и што је одмах започео са подизањем Жиче. Нико није пре ни боље наставио традицију његовог оца Немање, који није био само велик владар, него и велики градитељ.““(Кашанин 1970: 296). И у Рашкој он се пита како ће бити довршене живописом Студеница, Жича, Милешева. У куполи у Студеници остао је о томе запис: „И мене работавшаго помените Саву грешнаго, 1209.“ (Панић-Суреп 1962: 275-276)

Култ Светога Саве и легенда о њему пролазили су најразличитија искушења, баш као што је то било и с његовим српским народом. У вероватно најбезбожнијим временима, после Другог светског рата, било је остављено само Српској православној цркви да га, једино она, сме помињати и славити као оснивача и патрона, о чему је, не без смелости и не без великог ризика, писао Милорад Панић-Суреп. Али,

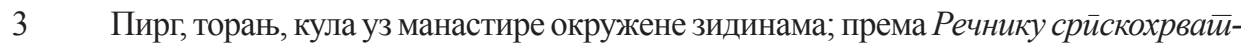
скої језика (1971) Матица српска / Матица хрватска, Нови Сад / Загреб 
осим тога, овај аутор је веома проницљиво тражио место за свеукупно историјско дело Саве Немањића. И нашао га је: као дипломате-политичара, црквено-државног организатора, културно-просветног радника и књижевника. (Панић-Суреп 1962: 272).

Велике вештине политичке и умећа дипломатског било је потребно до 1219. године када је изборио самосталност српске цркве. Ништа мање ни у међудржавним преговарањима, па ни у смиривању братских међусобица браће му Стефана и Вукана и синоваца Радослава и Владислава о наследству власти у отачаству: „Он је имао удела у вођењу и унутрашње и иностране политике, за дуг период од неких тридесе година. Учествовао је у решењу сукоба између Вукана и Стефана о наследству власти; ишао у Никеју да оконча преговоре с византијским царем и васељенским патријархом о аутокефалности српске православне цркве; био у прилици да крунише и саветује три краља - Стефана Првовенчаног, Радослава, Владислава - и да у њихово име води преговоре са иностраним владарима и црквеним управљачима. Посматран кроз историју, без присуства легендарсног и хагиографског осветљења, први архиепиксоп српски Сава I указује се, пре свега другог, као велики прелат цркве и као државник.“ (Кашанин 1970: 302).

Калуђер који служи човечанству и своме народу (Ковачевић 1959: 282), истицао је Божидар Ковачевић. И заиста, о томе можда понајбоље посведочују његове многобројне мисије, путовања до веома удаљених крајева и држава: „Ако не раније, он је у својој седамнаестој години, кад је примио на управу део Хума, пропутовао српске земље. Свету Гору је сву прошао за оних шеснаест година које је провео у њој као монах. Већ у раној младости, једно за другим, у два маха, посетио је Цариград, тадашњи центар хришћанства и светске културе. У другој византијској престоници, Солуну, где је произведен за архимандрита и радио на редиговању Номоканона, морао се осећати као код куће. Два пута је одлазио до Никеје, која је била жариште класицизма и центар византијских царских и црквених власти, и до Јерусалима, великог светског места хаџија и крсташа. Стигао је и до мистичне Синајске горе, у којој је провео четрдесет дана. Колико мора и земаља, градова и манастира, рукописа и икона, мозаика и фресака он није видео за својих путовања!“ (Кашанин 1970: 300).

На богата светска искуства, која је нештедимице даривао другима, како би им помогао да дођу до корисних знања, указивао је 
Панић-Суреп. Данас би се томе могло додати да је био не само светски путник него и светски човек, личност која је радо примана и на царски двор и уз патријаршијски трон: „Сава је познавао византијске цареве Алексија III, Теодора Ласкара, Јована Ватаца, Теодора Анђела, виђао се с васељенским патријархом Атанасијем и никејским Манојлом, био у пријатељству с архиепископом солунским Константином Месопотамисом. Ниједан Србин није у то време видео толико дворова и цркава, ни упознао толико и тако значајних личности као Сава. Колико о књижевним написима и уметничким радовима, он је знао судити о држању и поступцима људи.“ (Кашанин 1970: 300).

После осамостаљења српске цркве започиње велику и суштинску реформу и цркве и државе. Мора бити да је тај подухват главни за схватање Светога Саве као творца нације: „Вративши се у земљу као архиепископ посвећен од васељенског патријарха и подршком наследника византијских василеуса, Сава изводи грандиозну црквено-државну реорганизацију. Отрже српску цркву од охридске јуристикције, на место једне образује осам епископија, епископије дели на протопопије, а ове на општине, протерује свештенике туђе држављане и на њихова места поставља своје младе ученике. Седишта епископија размешта, као тврђаве, по границама српских земаља. На тај начин добијено је оно што је недостајало централној власти.“ (Панић-Суреп 1962: 275)

Препород цркве и државе, после реформе, не би могао имати онолико далекосежне резултате без просвећивања и просвећености, нити без просвете: „Овај умни човек био је начисто с још једном неминовношћу: да је српском народу потребна и једна друга еманципација поред политичке и црквене, а то је културна. И то она као друштвена компонента која повезује сва друга настојања обезбеђујући им континуитет и трајност“. (Панић-Суреп 1962: 275). Још на Светој Гори прихватио је покрет калуђера који су се старали о ревизији правописа и ћирило-методијевског словенског језика. Резултат тога било је укидање застарелих словних знакова назала, замена одумрлих новим народним речима... Плански се преводи с грчког језика. У ту сврху настаје у Хиландару читава школа. Ту је, дакле, започета редакција старословенских текстова.

Али, тако започета, Савина културна прегалаштва стремила су далеко шире и увелико далекосежније: „Сава је зачетник просвете. У његовој цркви архитектура, дрворез, сликарство, ситна уметност 
али ванредна, обрада злата, сребра, ткања и везова, која тек има да се прослави и која је, што је у њој битно и лепо, не само оригинална него и наша, балканска, развијаху се у његовим традицијама. Писменост свештенства, почетак школа, писменост уопште у нас, вековима, Савина је заслуга.“ (Црњански 1934: 293).

У просветне заслуге његове мора се истаћи и Законойравило, Номоканон или Крмчија. ${ }^{4}$ Вредно је зато подсетити данас како је настајало, који су му били узори и који све извори на основу којих је настало: „У старој Византији било је доста крмчија; једна од њих била је тзв. $\mathrm{Cu}$ нойсис, из VI века, где је укратко дат текст разних црквених правила. Крајем IX века израђен је нов номоканон, пун, а не скраћен (и пре је било таквих), и са допунама из последњег доба; тај је из времена патријарха Фотија, из године 883. У ХІІ веку Синойсис је добио два коментара: један од Алексија Аристина, други од Јована Зонаре. Наш Сава је од свега тога начинио своју Крмчију. У њу су ушли Синойсис и коментари Аристина и Зонаре; Фотијев Номоканон такође је узет у обзир тада. У њу даље ушао и цео Прохирон, тј. Граяски закон, а то је световни правни зборник IX века, али који је садржао законе који се тичу цркве (брачно право и др.); ушли су још и изводи из Јустинијанових новела. Савина Крмчија није прост препис или превод, него нарочита, самостална и смишљена компилација најбољих црквено-законских књига грчких онога доба.“ (Поповић 1934: 269). У трима православним црквама - Српској, Бугарској и Руској - Номоканон Светога Саве није изгубио од своје актуелности ни до данас, ни после готово осам векова од кад је настао. ${ }^{5}$

4 Др Миодраг М. Петровић објавио је књигу о Законойравилу Светога Саве 1990. и приредио фототипско издање Законойравила према Иловичком препису из 1262, најстаријем сачуваном, да би га објавио 1991. године.

5 „Свети Сава Српски, како га с љубављу називају у Русији, написао је на пергаменту Крмчију или, како сам пише, Законойравило које постаде званични ірађански кояекс у Србији од 1219, у Бугарској од 1221. и у Русији од 1272. године и ирквени коgекс у Српској, Бугарској и Руској православној цркви. После неколико векова примене овај кодекс је изгубио статус званичног грађанског кодекса, али није изгубио на значају јер у овим земљама и даље представља обичајно право, одређује морал и менталитет народа. Као црквени кодекс Крмчија је до данашњег дана остала званични црквени кодекс у Српској, Бугарској и Руској православној цркви.““ ( Митровић, Божидар Трифунов (2006) РасСија (КолоВенија) најситарија цивилизација и срйски чуgойворичи, „Пешић и синови“/ „Архимедес“, Београд, стр. 77) 
Свети Сава је први српски средњовековни писац, књижевник, једини који носи светитељско име, на шта указује Милан Кашанин, али такав писац који није на свој књижевни рад гледао као на први и најважнији позив. У попису дела његових наводе се: Хиланgарска

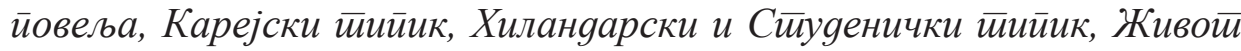
Симеона Немање, Служба св. Симеону, Писмо Сииирияону, Уйуйсииво ономе који хоће gа чийа овај йсалииир и Крмчија. Списатељском раду Светога Саве посвећена је значајна литература. Из обиља бисмо извојили само два мишљења о једном месту из тога дела. Милан Кашанин: „Животопис Немањин, који је Сава саставио у пресудним тренуцима народнога и свога живота, иде међу најсадржајније и најбоље написане списе на народном језику. Он је светска вредност.“ (Кашанин 1970: 295). Божидар Ковачевић: „Тај спис, Живой свейоїа Симеона, класично је дело на свој начин, и неки његови делови, као, на пример, опис Немањине смрти, по својој вредности не стоје испод описа Сократове смрти, наравно, кад се при том има на уму да су ова два текста настала на различитим психолошким основама и у веома неједнаким условима.“ (Ковачевић 1959: 290)

Из тмине векова још је торжественији светлозарни лик Светога Саве. И трајнији од свих других. Онај што може неодступно да побуђује национални осећај врлине. И који је, дабоме, свеприсутан за очи које желе да га виде: „Али, као ни један црквени управљач или владар, Сава је, мртав, био свуд присутан. Није један манастир био његов, него сви - у свакој цркви су се налазили његов портрет и његове мисли. Турци, желећи учинити да га нема, смислили су да му спале тело. И тако су и учинили. Али, као што бива с незаменљивим личностима и у мрачним епохама, оно се тад није расуло у прах, него у светлост.“ (Кашанин 1970: 314).

\section{Друштво „Свети Сава“ - најстарије у српском народу}

Најстарије културно, просветно и хуманитарно друштво у српском народу, које носи име Светога Саве, траје од 1886. године. Основао га је у Београду Светомир Николајевић, професор Велике школе, заједно са својим истомишљеницима. Настало је у времене када је српски народ на балканским просторима живео у различитим 
државама и под различитом влашћу, и то властима несклоним да га подупиру а сасвим склоним да га тлаче и однарођују, па је тако из српске престонице потекла иницијатива да се помогне своме народу и то, пре свега, књигом, знањем и просветом. Схватало се да је духовно и културно, а онда и национално уздизање тога нашег народа изван матице прва и најпреча задаћа. Тако је у „Основним правилима“ Друштва „Свети Сава““ већ отад и већ у првом члану било записано да „шири просвету и негује национална осећања и врлине у српском народу..." (Брайсииво 15: 21)

Хроничар и летописац Друштва професорка др Јасна Јанићијевић истиче у својим многобројним текстовима делатности на школовању младих људи из тих наших крајева, на оснивање школа и других просветних установа, на разноврсну и нарочито материјалну помоћ, али изнад свега и на делотворно смислен рад с младима како би очували језик, културу и национални идентитет. За остварење таквих стремљења створена је веома респектабилна материјална основа. У Београду, широм Србије, али и у некадашњој Краљевини Срба, Хрвата и Словенаца и доцније Краљевини Југославији грађене су куће, куповани или добијани на поклон плацеви, станови и друга материјална добра, која је затим баштинило и којима је располагало Друштво „Свети Сава“. Захваљујући томе био је обезбеђен несметан рад. Оснивани су пододбори по целој Србији, објављиване су књиге и друге публикације, а од посебног значај било је гласило, годишњак „Братство“, у коме су објављивали прилоге најумнији људи онога времена. Осим што је помагало просветне, културне и друге установе, Друштво је бринуло о надареним а сиромашним ђацима и студентима, својим благодејанцима, ${ }^{6}$ дајући им стипендије и омогућавајући им школовање. Бесплатно су слате књиге школама, народним читаоницама и културним установама, као и својим члановима. До почетка балканских ратова Друштво је имало у Београду основну и продужну школу кроз које је прошло 20000 деце из неослобођене Јужне Србије и Босне и Херцеговине.

6 Ученик (обично сиромашан, одличног учења и примерног владања) који добива издржавање или помоћ за издржавање, стипендист; према Речнику

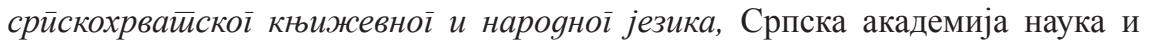
уметности / Институт за српскохрватски језик, 1959, Београд 
Током Великог рата Друштво „Свети Сава“ није радило, а после Првог светског рата наставило је своју делатност. Додуше, околности су биле знатно измењене, па и због тога што се у заједничној држави нашао велики део српскога народа. Али, ни сви позиви ни сва настојања да се приволе на сарађују интелектуалци других народа „троједне“ Краљевине нису давали готово никакве резултате. Но није се стало. Баш у том међуратном периоду Друштво је у Београду, на Дорћолу, подигло две велелепне зграде, у Улици цара Душана број 11 и 13, од којих је једна Светосавски дом, док је другу, велелепну четвороспратницу с модерно уређеним луксузним становима, наменило издавању под кирију, да би и од тога увећавало приходе и могло да их даље употребљава за остварење културно-просветних циљева.

Ни током Другог светског рата Друштво „Свети Сава“ није радило, делећи тако судбину свога народа. У бомбардовањима Београда и другим ратним разарањима претрпело је велику штету на непокретним добрима. Али, највећа штета тек је имала да настане, после ослобођења, онда када су нове власти одлуком од 22. маја 1945. године забраниле рад Друштва, а затим га сасвим разбаштиниле одузевши му целокупну имовину.

Задуго је мало ко веровао да би Друштво „Свети Сава“ могло да се опорави и да икад обнови рад. На срећу, то се ипак догодило. Али, и потом, уз не мале тешкоће. Пишући о томе објективно и критички, професорка др Јасна Јанићијевић наводи и следеће: „Обнова Друштва 'Свети Сава' започела је с великим надама 1994. године, више од пола века од његовог укидања почетком Другог светског рата. Почетни ентузијазам није дуго трајао и значајна имена из савремене српске културе и науке убрзо су се повукла, остављајући Друштво неколицини оних који су настојали да сачувају традиционалне вредности једне овако старе и угледне институције. Најтеже је било снаћи се за средства и у томе су посебно помогли тадашње Министарство културе и Министарство вера Србије. Осиромашени грађански слој друштва који је увек био окосница и потпора Друштва `Свети Сава' изгубио је свој значај, углед и моћ, па и могућност да га материјално помаже. Отуда су активности Друштва, посебно оне у вези са бригом за Србе у расејању, морале да буду сведене на најмању меру. Међутим, неке друге које имају важности и смисла у данашње време, избиле су у први план.“ (Брайсииво 10: 19). 
Уз обновљен рад обновљен је часопис „Братство“, као важна карика која повезује некадашње с данашњим Друштвом „Свети Сава“. И данас, баш као некад, ангажују се угледни ствараоци из света науке, културе и уметности као сарадници. У својству главног и одговорног уредника предано и посвећено ради професорка др Злата Бојовић заједно с уређивачким одбором. Уређивачка политика часописа и данас почива на провереним и строгим мерилима која су постављена пре више од сто година, а у сваком новом броју нађе се место и за неки драгоцен текст из старог часописа коме време није могло да умањи вредност, и који се на овај начин чува од заборава.

„Делатност која представља новину у раду Друштва је редовна годишња трибина која окупља угледне научнике и значајне културне посленике и која својим бираним програмима привлачи пажњу публике“, писала је професорка Јанићијевић додајући: „Преко предавања, различитих типова излагања или мултимедијалних програма, обележавају се значајни датуми из наше културне историје, велике годишњице историјских збивања или јубилеји истакнутих појединаца. Већина излагања се касније у облику писаних чланака објављује у текућим бројевима часописа `Братство““. (Брайсӣво: 20).

У традиционалне активности Друштва убраја се наградни конкурс за ђаке основних и средњих школа који шаљу слободне саставе о Светом Сави. О слави 27. јануара, на Савиндан, награђују се најбољи ученички радови. Из године у годину све је више песама, прича и есеја, који стижу из многобројних школа из Србије, Републике Српске и других крајева. После првог петогодишта Друштво је објавило збирку награђених радова под насловом „Млади Светом Сави“.

Доследно и упорно залагала се професорка др Јасна Јанићијевић за још један облик рада Друштва, вредан и увелико потврђен, а то је оснивање пододбора. На томе је и инсистирала и о томе је писала: „Оно, међутим, што је за Друштво 'Свети Сава' данас још једна важна карика која би га везивала за првобитно Друштво, јесте оснивање његових пододбора у другим местима и градовима Србије. Желећи да и даље шири основну мисао водиљу чувања националне свести и врлине, као и духа светосавља, нарочито међу школском омладином, Друштво оснива своје пододборе који као самосталне, неполитичке организације раде у истом смеру. Мењају се идеали једног народа, 
мењају се историјске околности у којима он живи, мења се чак и његова географија и границе, али национална свест мора да чува своје основне вредности: свест о самобитности и аутентичности српства, пре свега о његовом културном и духовном идентитету. Један од начина да се то сачува јесте и постојање организација попут Друштва 'Свети Сава'. Својим залагањем, деловањем и сталном присутношћу, оно, заједно са својим пододборима, чува свест о српском националном бићу и преноси га даље, увек се држећи максиме Светомира Николајевића - да се не отима туђе, али и да се брани своје.“ (Брайстиво 10: 20)

Тако је писала и говорила професорка др Јасна Јанићијевић. Веома се уздала и у најављени Закон о реституцији, који нажалост није дочекала, а на основу којег би и Друштву „Свети Сава“ требало да буде враћена не мала и нипошто праведно одузета имовина. У понеким ситуацијама, као генералном секретару Друштва, њој није било лако да објасни, ни себи ни другим члановима, што су подстанари упркос толиким кућама и многим другим веома вредним непокретним добрима на које Друштво има тапије, као ни што ишту помоћ и готово милостињу док од њиховог некадашњег богатства други данас остварују огромну корист. Али ни такве околности нису је обеснаживале да дела у корист Друштва, верујући да је и то дужна у име његових узвишених циљева.

У седамнаест свезака часописа „Братство“, органу Друштва „Свети Сава“, у текстовима који су на известан начин летопис, оставила је професорка Јанићијевић много драгоцених информација. Мношто критичких и мудрих промишљања. Верујемо да ти текстови такође заслужују да буду убудуће подробније проучени.

$$
* * *
$$

На примеру делатности професорке Јасне Јанићијевић у Друштву „Свети Сава“ могли бисмо закључити да је она веома несебично приложила своје велико искуство и мудрост зрелог научника. Модерне теорије, које је проучавала, актуелна стремљења у науци, које је радознало упознавала, као и многе иновативности у различитим културним срединама, којима се такође бавила, сматрала је нарочито плодоносним тек ако могу бити применљиви и у нашем духовном и културном простору. Толико пута је подвлачила и - неговање 
националног осећања врлине - уз најузоритији култ Светога Саве, сматрајући да је у томе понајбоље оличен и дух традиционалног и дух модерног и космополитског. И заиста, Свети Сава Српски присутан је од Свете Горе у Грчкој, преко Трнова у Бугарској, до московског Кремља у Русији, али и у манастирима од Аустралије до Сједињених Америчких Држава. Нико нам на све то није тако указао, нити толико приближио, као што је то, смерно али и смело, учинила професорка др Јасна Јанићијевић.

\section{Литература}

Анйолоіија сииаре срйске књижевностии (XI - XVIII века) (1960) избор, преводи и објашњења Ђорђа СП. Радојчића, „Нолит“, Београд;

Богдановић 1991: Богдановић, Димитрије (1991) Сйара срӣска

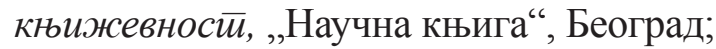

Ковачевић 1959: Ковачевић, Божидар (1959) Свешии Сава у своме времену, "Стара књижевност“, приредио Ђорђе Трифуновић, „Нолит“, Београд

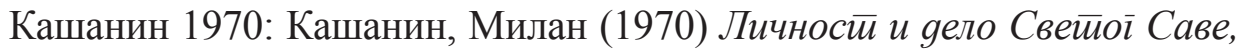
„Стара књижевност“, приредио Ђорђе Трифуновић, „Нолит“, Београд

Митровић 2006: Митровић, Божидар Трифунов (2006). РaCuја (КолоВенија) Најстиарија циивилизација и срӣски чуgойворичи, „Пешић и синови“, Београд;

Панић-Суреп 1962: Панић-Суреп, Милорад (1962) Дело Свейой Саве, „Стара књижевност“, приредио Ђорђе Трифуновић, „Нолит“, Београд

Пинтер 2011: Пинтер, Харолд (2011). Нови свейски йореgак. „Архипелаг“, Београд;

Поповић 1934: Поповић, Павле (1934) О кьижевном gелу Свейої Саве, “Стара књижевност“, приредио Ђорђе Трифуновић, „Нолит“, Београд

Поточан 2011: Поточан, Будимир (2011). Og локалне gо іллобалне информације - мулииияисиийлинарно истираживање, Мегатренд, Београд; 


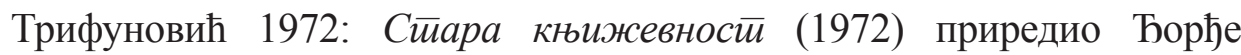
Трифуновић, „Нолит“, Београд;

Трифуновић 1974: Трифуновић, Ђорђе (1974) Азбучник срйских среgюовековних йојмова, „Вук Караџић“, Београд;

Речник срйскохрвайскої књижевної и наровної језика (1959) књигапрва, Српска академија наука и уметности / Институт за српскохрватски језик, Београд;

Речник срйскохрвайскої језика (1971) Матица српска / Матица хрватска, Нови Сад / Загреб;

Братистиво - од броја 1, године 1997. до броја 17, године 2013. Црњански 1934: Црњански, Милош (1934) Сава Немањић уиеемељьиеељ срйске кулимуре, "Стара књижевност", приредио Ђорђе Трифуновић, „Нолит“, Београд

Budimir Potočan

\section{Summary}

\section{BEFORE THE BLISSFUL IMAGE OF SAINT SAVA AND ASSOCIATION "SAINT SAVA" - JASNA JANICIJEVIC, PHD}

Scientific work practiced by sociologist, culturologist and communicologist Jasna Janicijevic, $\mathrm{PhD}$ is based on contemporary and modern scientific views such as theory of information, communication and reception. Comparably and in parallel, her professional and scientific work is dedicated to spiritual values of tradition. In the latter segment, the most important is her ongoing engagement in the Association "Saint Sava", where she has been working for almost a decade with extraordinary dedication and devotion.

Key words: Association "Saint Sava", education, tradition, national, virtue 